\title{
Comment
}

Identifying withdrawal phenomena is important when treating chronic disease such as angina. The patient or his physician may stop the antianginal medication for various reasons without realising the potential problems which may arise. If withdrawal syndromes exist, it is essential that they should be clearly recognised and the potential complications anticipated.

Our observations indicate that withdrawal of calcium antagonists may be associated with severe angina, a phenomenon which has also been described with beta-adrenergic-blocking drugs. ${ }^{5}$ The mechanism of this withdrawal syndrome is unknown. Movement of calcium ions across the membranes of smooth-muscle cells of the coronary arteries is known to maintain arterial tone and the ability of the arteries to contract spasmodically. If the intracellular calcium ion values were depleted by chronic treatment with drugs blocking calcium entry, an artificial situation in which a normal extracellular calcium value and a low intra-cellular calcium value may be created, producing an increased "calcium gradient" across the cell wall. When the drugs are stopped there could be an increased movement of calcium ions into the cells producing a considerably increased tendency for the coronary arteries to go into spasm. Other contributing and provocative mechanisms may possibly play a part in this phenomenon.

The true incidence of this phenomenon is difficult to assess. These cases were encountered during routine ambulatory monitoring of 143 patients on calcium antagonist trials yielding an incidence of about $3.5 \%$, similar to a reported $5 \%$ incidence of withdrawal symptoms during beta-blocker treatment.

Dr V Bala Subramanian is supported by the British Heart Foundation.

Requests for reprints should be sent to Dr E B Raftery.

Schamroth L. The philosophy of calcium ion antagonists. In: Zanchetti A, Krikler DM, eds. Calcium antagonism in cardiovascular therapy. Experience with verapamil. Amsterdam: Excerpta Medica, 1981:5-9.

Bala Subramanian V, Paramasivan R, Lahiri A, Raftery EB. Verapamil in chronic stable angina: a controlled study with computerised treadmill exercise. Lancet $1980 ; \mathrm{i}: 841-4$.

"Bala Subramanian V, Bowles M, Lahiri A, Davies AB, Raftery EB. Longterm antianginal action of verapamil assessed with quantitated serial treadmill stress testing. Am 7 Cardiol $1981 ; 48: 529-35$.

4 Bala Subramanian V, Lahiri A, Raftery EB, Green H, Stott FD. Ambulatory ST segment monitoring. Problems, pitfalls, solutions and clinical application. Br Heart 7 1980;44:419-25.

"Shand DG, Wood AJJ. Propranolol withdrawal syndrome-why? Circulation 1978;58:202-3.

(Accepted 13 ()ctober 1982)

Department of Cardiology and Division of Clinical Sciences, Northwick Park Hospital and Clinical Research Centre, Harrow, Middlesex HA1 3UJ

V BALA SUBRAMANIAN, MD, FACC, honorary consultant

$M$ J BOWLES, MRCP, honorary registrar

N S KHURMI, MB, BS, research assistant

A B DAVIES, MRCP, honorary senior registrar

$M$ J O'HARA, MRCP, honorary registrar

E B RAFTERY, FACC, FRCP, consultant cardiologist and group director

\section{Simultaneous primary infections with Epstein-Barr virus and measles virus in fatal acute encephalitis}

We present the first published report of a case of fatal encephalitis in which infection took place simultaneously with Epstein-Barr virus and measles virus. It is also the first report of $\operatorname{IgM}$ antibodies to Epstein-Barr virus being found in the cerebrospinal fluid.

\section{Case report}

A previously healthy 11 year old boy was admitted to a general hospital with headache and transient fever. Four days after admission he developed nausea, vomiting, double vision, tremor, and vertigo and he had hyperactive

reflexes and severe ataxia. The next day he had amnesia and convulsions, temperature had risen to $40^{\circ} \mathrm{C}$, and he went into a coma. Findings of contrasted computed tomography were normal. Cerebrospinal fluid pressure, cell count, and protein value $(0.60 \mathrm{~g} / \mathrm{l})$ were within normal ranges. The boy was subsequently transferred to Rigshospitalet, Copenhagen, in coma, with universal hypotonia, Babinski's sign on the right side, and absent corneal reflexes. He also had bilateral tonsillitis with trismus. Blood count showed a white cell count of $7.3 \times 10^{9} / 1(61 \%$ lymphocytes, of which many were atypical cells, and $38 \%$ neutrophils). Repeated lumbar puncture yielded clear cerebrospinal fluid containing $14 \times 10^{6} / 1$ white cells ( $78 \%$ mononuclear), no red cells, a glucose concentration of $5.3 \mathrm{mmol} / 1(95 \mathrm{mg} / 100 \mathrm{ml}$ ) (plasma glucose concentration being $7 \cdot 4 \mathrm{mmol} / 1(133 \mathrm{mg} / 100 \mathrm{ml})$ ), and a protein concentration of $3.88 \mathrm{~g} / \mathrm{l}$. A limulus test for the presence of endotoxin in the cerebrospinal fluid gave negative results. A virus infection with encephalitis was suspected, and the boy was treated with acycloguanosine. Clinical impression of increasing intracranial pressure prompted treatment with mannitol, frusemide, and corticosteroids, but there was no improvement. The boy died eight days after appearance of the initial symptoms. Necropsy showed diffuse oedema of the brain but no macroscopic meningeal reaction. Light microscopic examination of brain biopsy specimens showed extensive perivascular lymphocyte infiltrations.

This patient was exposed to two primary infections simultaneously, one due to Epstein-Barr virus and the other to measles virus. The diagnosis of infectious mononucleosis was supported by the clinical picture and doublechecked serologically with the findings of IgM antibodies specific for EpsteinBarr virus in serum (titre 1/320) and cerebrospinal fluid (1/2), a heterophil antibody response, a high serum Epstein-Barr viral capsid antigen (IgG) titre $(1 / 640)$, and a serum antibody response to the diffuse component of early antigen to Epstein-Barr virus $(1 / 10)$. The primary measles infection was shown by a positive result to a measles-specific IgM test (enzymelinked immunosorbent assay) ${ }^{1}$ in serum $(0.55)$ and cerebrospinal fluid $(0 \cdot 16)$, controlled for unspecific rheumatic factor. Furthermore, high titres were found on complement fixation test $(1 / 128)$ and measles-specific IgG test (enzyme-linked immunosorbent assay, 1.90). Antibody values were also obtained in cerebrospinal fluid (complement fixation test result 1/4, enzyme-linked immunosorbent assay $1 \cdot 61$ ). The cut-off value in both enzymelinked immunosorbent assays was $0 \cdot 15 .^{1}$ No clinical evidence of measles was observed. Serum antibodies to adenovirus, influenza virus $A+B$, respiratory syncytial virus, and parainfluenza virus were all within normal ranges, no antibodies being found for cytomegalovirus. No herpes simplex virus was found in cerebrospinal fluid. At necropsy, brain and lung tissue were cultured for herpes simplex virus and cytomegalovirus, but not for measles virus or Epstein-Barr virus. All cultures were negative. The ratio of cerebrospinal fluid albumin to serum albumin was high $\left(68.2 \times 10^{-3}\right.$, normal range: $2 \cdot 7-8 \cdot 3 \times 10^{-3}$ ), but the IgG index derived from the ratio fell within normal range.

\section{Comment}

Primary lethal infection with two viruses at the same time has been reported in a few cases ${ }^{2-4}$; this is the first report of simultaneous lethal infection with Epstein-Barr virus and measles virus in a patient with encephalitis. Infection with Epstein-Barr virus seldom causes severe central nervous system symptoms but the cell-mediated immune functions are suppressed in the early stages of infectious mononucleosis. Infection with measles virus also causes immune suppression, and measles encephalitis may be severe and have lasting sequelae. Considering that measles infection in children with congenital $\mathrm{T}$-cell deficiency has a poor prognosis, we suggest that the grave central nervous system symptoms in our patient were secondary to the combined immunosuppressive effects of the two virus infections. Our finding of antibodies in the cerebrospinal fluid could be due exclusively to passive diffusion, as judged from the relatively high albumin ratio. However, the quantitative/qualitative value of bloodbrain barrier tests are still under debate. ${ }^{5}$ Furthermore, earlier reports have confirmed the possibility of local production of antibodies in cerebrospinal fluid, and the possible passive transfer of albumin and IgG does not guarantee transfer of the much larger IgM molecule.

We conclude that in cases of unusually severe virus encephalitis it might be worth while to check for infection with more than one agent, and if possible to look for changes in the various T-cell subpopulations.

Requests for reprints should be addressed to Mads Melbye.

This study was supported by the Danish Cancer Society (grant M-14/81). We thank the laboratory of paediatric pathology, Rigshospitalet, Copenhagen, for conducting the histological examination.

' Pedersen IR, Antonsdottir A, Evald R, Mordhorst CH. Detection of measles IgM antibodies by enzyme-linked immunosorbent assay (ELISA). Acta Pathol Microbiol Scand [B] 1982;90:153-60.

2 Bland JD, Lilleyman JS. Fatal pneumonia associated with two viruses in a child with lymphoblastic leukaemia. $\mathrm{Br} M e d$ f 1982;284:82.

${ }^{3}$ Smith RH. Fatal adenovirus infection with misleading positive serology for infectious mononucleosis. Lancet $1979 ; \mathrm{i}: 299-300$. 
4 Feorino PM, Humphrey D, Hochberg F, Chilicote R. Mononucleosisassociated subacute sclerosing panencephalitis. Lancet 1975;ii:530-2.

${ }^{5}$ Peterslund NA, Pedersen B. Liquor: serum quotients of IgG and albumin in patients with meningism, meningitis, and multiple sclerosis. Acta Neurol Scand 1982;66:25-33.

(Accepted 27 October 1982)

Institute of Cancer Research, Radiumstationen, DK-8000 Aarhus C, Denmark

MADS MELBYE, medical student

PETER EBBESEN, MD, head of institute

Department of Infectious Diseases, Rigshospitalet, DK-2100 Copenhagen $\phi$, Denmark

NIELS JACOBSEN, MD, registrar

Ornithosis Department, Statens Seruminstitut, DK-2300 Copenhagen S, Denmark

CARL H MORDHORST, MD, head of department

\section{Association between alcohol consumption and adult pedestrians who sustain injuries in road traffic accidents}

We studied 50 consecutive pedestrians who were victims of road traffic accidents and 50 controls to assess the influence of alcohol in pedestrians involved in accidents and on the severity of the injuries sustained.

\section{Subjects, methods, and results}

Blood alcohol equivalents were obtained from breath samples with a Lion Alcolmeter. In eight patients with severe injuries the alcohol concentration was estimated from blood samples. One week after the accident, and within 30 minutes of the time of the accident, controls were obtained by approaching the first passer by of the same sex and roughly the same age as the patient at the site where the accident had occurred.

The patient and control groups both comprised 27 men and 23 women. Patients were aged 13-72 years (median 26 years). Differences in age between patients and controls were small (mean $0 \cdot 4$, SD $3 \cdot 0$ years). Differences between the time of testing patients and their matched controls ranged from 0 to 45 minutes (median 10 minutes). On 46 occasions the first person approached to serve as a control agreed to give a breath specimen. The mean blood alcohol concentration in patients who had been drinking was $36.9 \mathrm{mmol} / 1(170 \mathrm{mg} /$ $100 \mathrm{ml}$ ) (range $13 \cdot 0-73.8 \mathrm{mmol} / 1(60-340 \mathrm{mg} / 100 \mathrm{ml})$ ) and in controls who had been drinking $20.0 \mathrm{mmol} / 1(92 \mathrm{mg} / 100 \mathrm{ml}$ ) (range $6 \cdot 5-39 \cdot 1 \mathrm{mmol} / 1$ $(30-180 \mathrm{mg} / 100 \mathrm{ml})$ ).

Alcohol was not detected in both patient and control in 27 of the patientcontrol pairs and was detected in both subjects in 12 pairs. In the remaining 11 pairs the patients yielded a positive result on blood alcohol testing and the controls a negative result. McNemar's test confirmed that patients were more likely to have been drinking $\left(\chi^{2}=9 \cdot 1, \mathrm{df}=1, \mathrm{p}=0.003\right)$. These figures give a lower $95 \%$ confidence limit of 2.5 for the relative risk of a pedestrian who has been drinking being involved in an accident.

Distribution of patients and controls by blood alcohol concentration and distribution of patients by injury severity score (ISS) and presence or absence of alcohol

\begin{tabular}{|c|c|c|c|}
\hline & No alcohol & $\begin{array}{c}\text { Alcohol } \\
0 \cdot 2-17 \cdot 4 \mathrm{mmol} / 1\end{array}$ & $\begin{array}{c}\text { Alcohol } \\
>17 \cdot 4 \mathrm{mmol} / 1\end{array}$ \\
\hline $\begin{array}{l}\text { Patients } \\
\text { Controls }\end{array}$ & $\begin{array}{l}27 \\
38\end{array}$ & $\begin{array}{l}5 \\
5\end{array}$ & $\begin{array}{r}18 \\
7\end{array}$ \\
\hline Relative risk & 1 & $1 \cdot 4$ & $3 \cdot 6$ \\
\hline $\begin{array}{l}\text { Severity of injury: } \\
\text { Mild (ISS 1-9) } \\
\text { Moderate (ISS 10-19) } \\
\text { Severe (ISS 20+) }\end{array}$ & $\begin{array}{r}24 \\
3\end{array}$ & 1 & \\
\hline
\end{tabular}

Conversion: SI to traditional units-Alcohol: $1 \mathrm{mmol} / 1 \approx 4.6 \mathrm{mg} / 100 \mathrm{ml}$.
The table shows the distribution of patients and controls according to the blood alcohol concentration, ignoring the matched pairs. From these figures an estimate of the relative risk of a pedestrian with a blood alcohol concentration of over $17.4 \mathrm{mmol} / 1(80 \mathrm{mg} / 100 \mathrm{ml})$ being involved in an accident is 3.6. The table also shows the injury severity score $^{1}$ of the patients against the presence or absence of alcohol in the blood. Comparison of the mildly injured patients with those moderately and severely injured yielded a positive association between alcohol concentration and more severe injury $\left(\chi^{2}=8 \cdot 1, \mathrm{df}=1, \mathrm{p}=0.004\right)$.

\section{Comment}

Crompton's recent survey ${ }^{2}$ of blood alcohol concentrations in 208 people who died in road accidents is difficult to evaluate because of the absence of controls. We have found only three previous studies of alcohol concentrations in pedestrians in which controls were used. Two were based on fatal accidents to pedestrians. Haddon et al studied 20 pedestrians who died within six hours after their accidents. Comparison with controls, matched by site, gave an estimated relative risk of 18 for pedestrians with a blood alcohol concentration of $21 \cdot 7$ mmol or more $/ 1(>100 \mathrm{mg} / 100 \mathrm{ml})$. Clayton et al ${ }^{4}$ compared 344 victims who died and 1118 controls. Their figures give a relative risk of having a fatal accident of 4.6 for pedestrians with a blood alcohol concentration of $17.4 \mathrm{mmol}$ or more $/ 1(80 \mathrm{mg} / 100 \mathrm{ml})$.

Honkanen et $\mathrm{l}^{5}$ reported a controlled study of live patients, of whom 313 slipped and fell and 28 were pedestrian victims of road accidents. The relative risk of slipping and falling was 29 for a blood alcohol concentration of $45.6 \mathrm{mmol} / 1(210 \mathrm{mg} / 100 \mathrm{ml})$; that of being involved in a pedestrian accident was estimated to be 10 if alcohol was detected in the blood.

Our controls were well matched for age, sex, time of day, day of week, and season of year. We do not believe that the association between blood alcohol concentration and a high injury severity score has been previously reported. Our study confirms the central finding of the three case-control studies reported above that there is a strong positive association between blood alcohol concentrations and road accidents to pedestrians.

' Baker SP, O'Neill B, Haddon W, Long WB. The injury severity score. A method for describing patients with multiple injuries and evaluating emergency care. $\mathcal{F}$ Trauma 1974;14:187.

2 Crompton MR. Alcohol and fatal road traffic accidents. Medicine, Science and the Law 1982;22:189-94.

${ }^{3}$ Haddon W, Valien P, McCarrol JR, Umberger CJ. A controlled investigation of the characteristics of adult pedestrians fatally injured by motor vehicles in Manhattan. F Chron Dis 1961;14:655-78.

1 Clayton AB, Booth AC, McCarthy PE. A controlled study of the role of alcohol in fatal adult pedestrian accidents. (Supplementary report 332 .) Crowthorne, Berkshire: Transport and Road Research Laboratory, 1977.

'Honkanen R, Ertarna L, Kuosmanen P, Linnoila M, Visari T. A casecontrol study on alcohol as a risk factor in pedestrian accidents. In Mattila M, ed. Alcohol, drugs and driving. Basle: Karger, 1976.

(Accepted 16 November 1982)

Musgrove Park Hospital, Belfast

S T IRWIN, FRCS, orthopaedic registrar

Queen's University, Belfast

C C PATTERSON, MSC, lecturer in medical statistics

Accident and Emergency Department, Royal Victoria Hospital, Belfast

W H RUTHERFORD, OBE, FRCS, consultant

\section{Correction}

Effects of amiodarone in thyrotoxicosis

We regret that two errors occurred in this article by Dr J Sheldon (22 January, p 267). Reference 3 should have read: Jaggarao NSV, Sheldon J, Grundy EN, Vincent R, Chamberlain DA. The effects of amiodarone on thyroid function. Postgrad Med f 1982;58:693-6. The last paragraph of the Comment should have read: "Thus amiodarone controls thyrotoxicosis clinically and biochemically but has no advantages over equivalent doses of iodine except for its antiarrhythmic effects, and it may delay subsequen control by carbimazole." 